
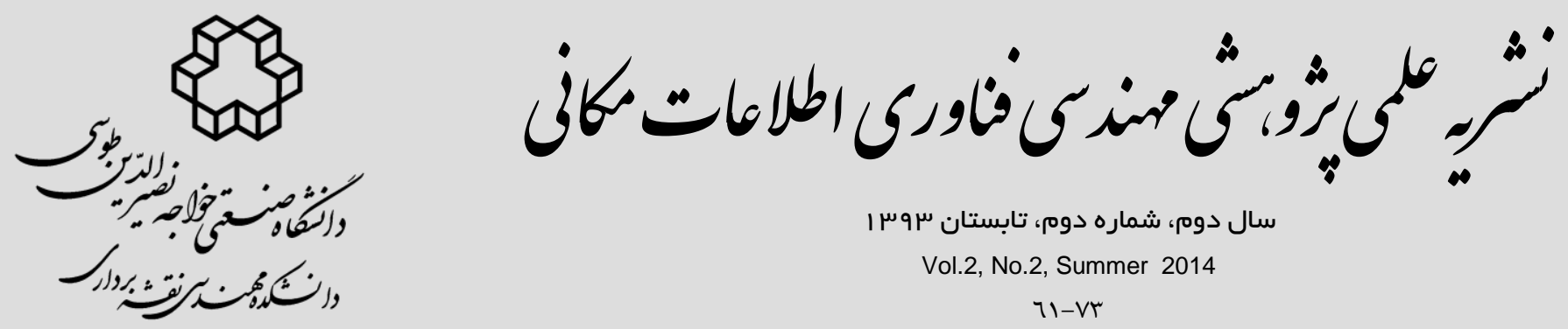

سال دوم، شماره دوهم، تابستان سوس |

Vol.2, No.2, Summer 2014

$71-V r$

ارائه الكوريتمى جديد بر مبناى تكنيك تداخل سنجى رادارى به منظور پايش فرونشست

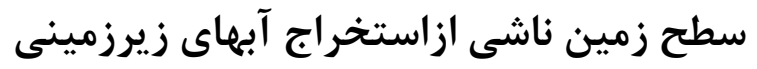

مريم دهقانى"

استاديار بخش راه، ساختمان و محيط زيست، دانشكده مهندسى، دانشكاه شيراز

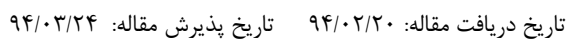

استخراج بى رويه از آبهاى زيرزمينى منجر به رخداد فرونشست زمين در منطقه ايى غير شهرى در زير حوضه مشهل واقع در شـمال شـرق ايــران

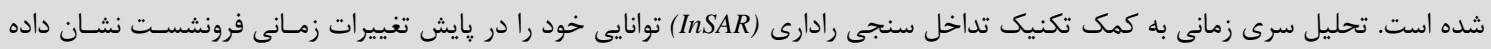

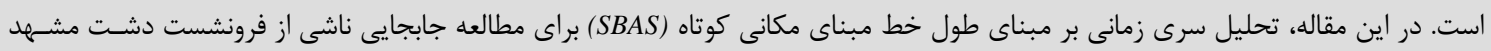

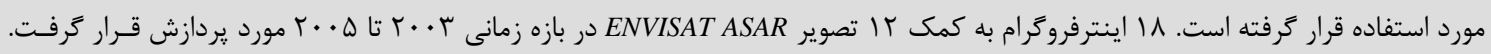

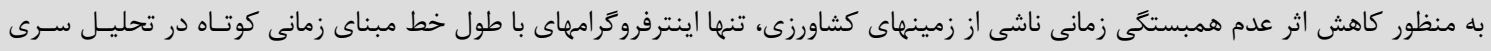

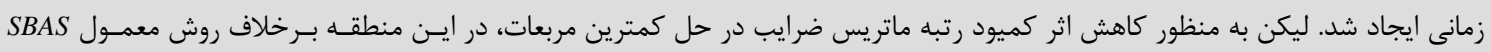

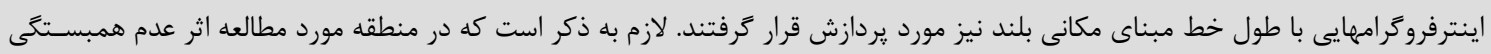

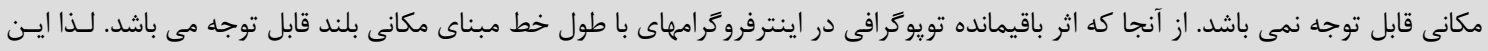

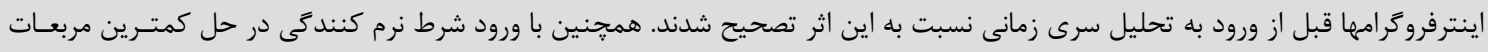

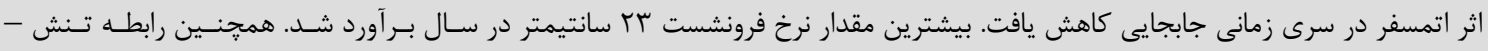

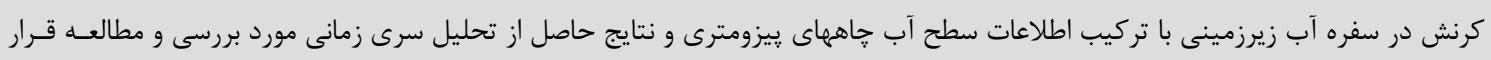

كليدوازهها: تداخل سنجى رادارى، تحليل سرى زمانى، فرونشست.

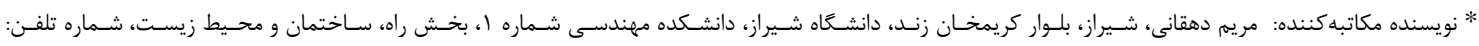
.VIrgitrigr Email: dehghani_rsgsi@yahoo.com 
سال مىباشد [1]. نرخ فرونشست در زيرحوضه مشهد در ابتـدا بـه وسـيله

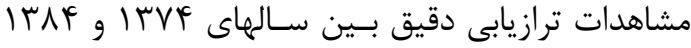

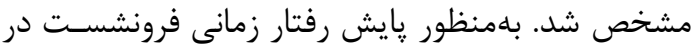

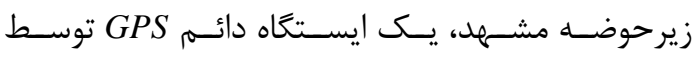

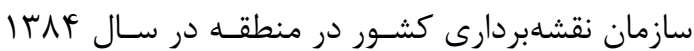

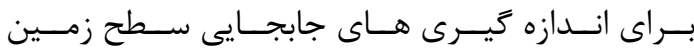
راهاندازى شد. لـيكن مشـاهدات ترازيـابى و GPS تنهـا

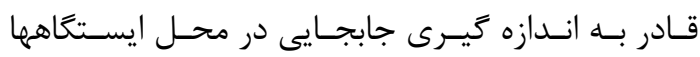

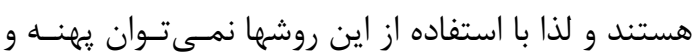

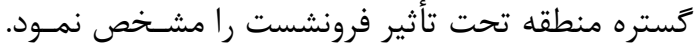

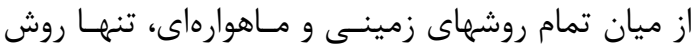

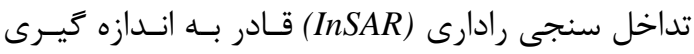

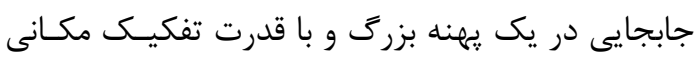

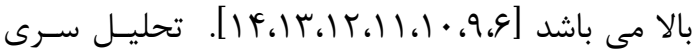
زمانى به كمك تعـداد قابـل تـوجهى از اينترفروخرامهـا

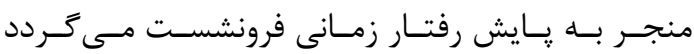
$[|\varepsilon| Q$, در اين مطالعه تحليل سرى زمانى به كمـك كا تصـوير

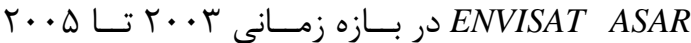

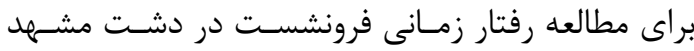

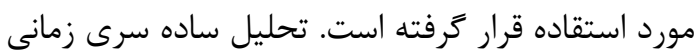

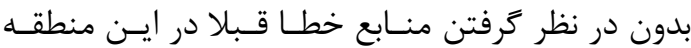

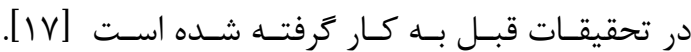

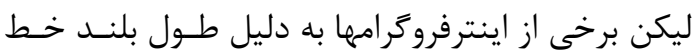

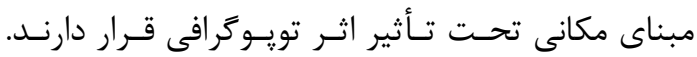
همجنين منابع ديخر خطا نظير اثرات اتمسـفرى منجـــر

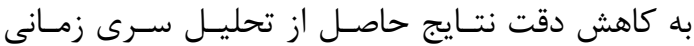

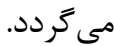

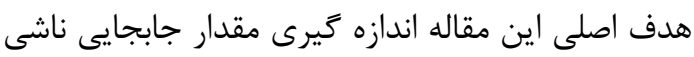

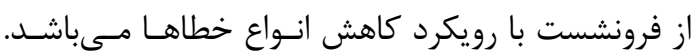
همجنين مكانيزم فرونشست در مقابل كاهش سطح آب

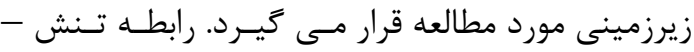

تغيير اقليم منجر به افزايش دما و بعضا كاهش متوسـط

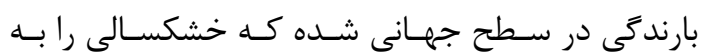
همراه داشته است. كاهش بارندكى و بديده خشكسـالى

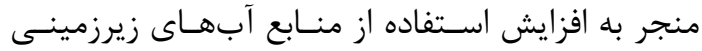

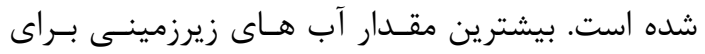
مصارف كشاورزى مورد استفاده قرار مى كيرد. همجنين افزايش جمعيت باعث افزايش تقاضا براى آب مى گَرـدد.

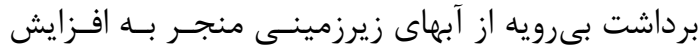

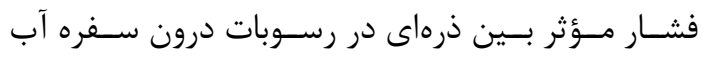

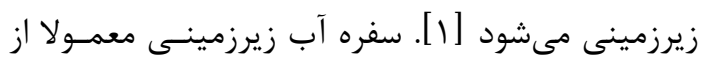
تعدادى ميان لايههاى ريزدانه كه قابليت تـراكم بـالايى دارند، تشكيل شده است. يايه نظرى تراكم ميان لايههـا

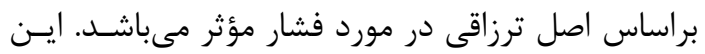
اصل بيان مى دارد هنكامى كه آب ازسفره خارج شـود،

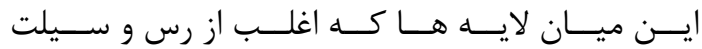

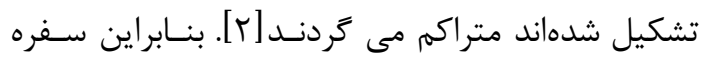

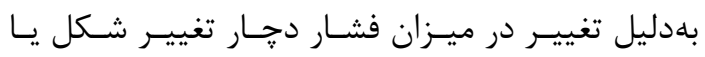

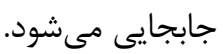
فرونشست ناشى از استخراج بى رويه آبهـاى زيرزمينسى به همراه بيامدهاى زيست محيطى آن در اكثر دشتهاى

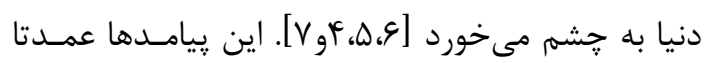
شامل آسيبهاى جبران نايذير به ساختارهاى مهندسى

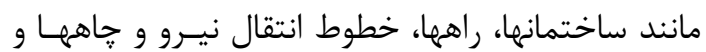

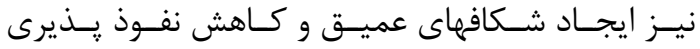

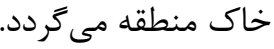

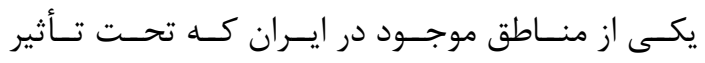

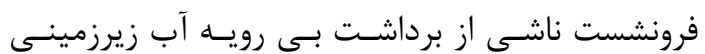
قرار دارد، دشت مشـهمد اسـت. شهر مشهمد در شـمال شرق ايران قراردارد كه از نقطـهـ نظــر جمعيـت دومسين

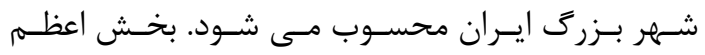

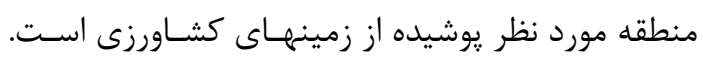
بنابراين، استخراج بى رويه آبهـاى زيرزمينسى از خاههيا

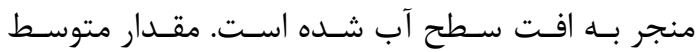




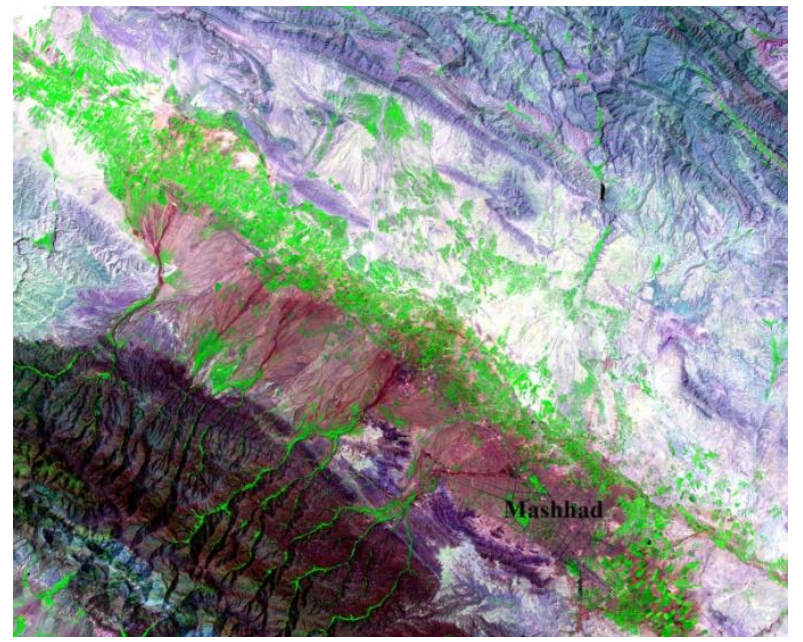

شكل ا- تصوير ماهواره LANDSAT ETM. مناطق

سبز رنت يوشش تياهى را نشان مي دهد.

- - - 1ادههاى موجود

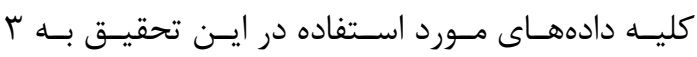

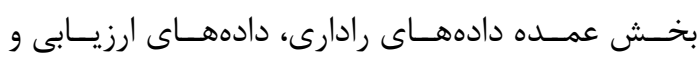

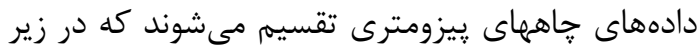
در مورد هر يك توضيح داده شده است.

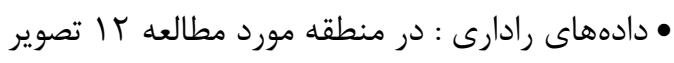
ENVISAT ASAR سـطح صـفر كه از مسـير شـماره

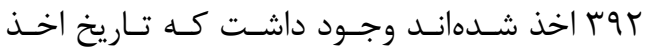

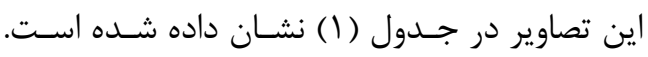

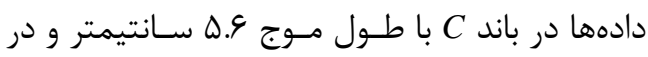

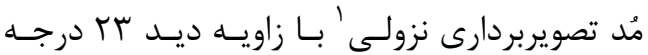
اخذ شدهاند.

شكل (T) در منطقه بزر كنمايى شده بخشى از شهر

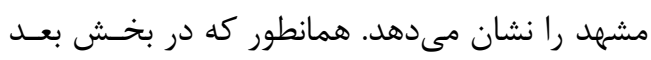

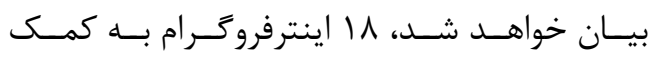

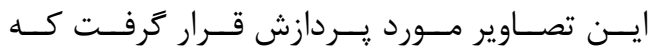
سعى شده است تا طـول خـط مبنــاى زمـانى آنهـا

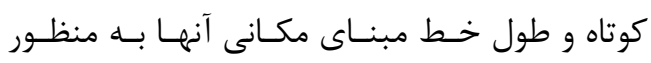

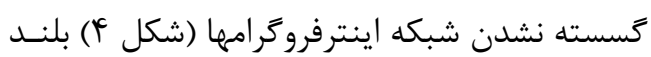

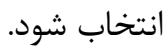

كرنش با استفاده از انـدازه كيريهـاى تــاخل سـنجى و

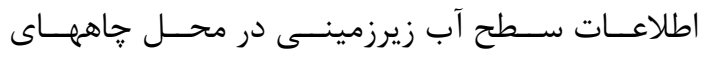

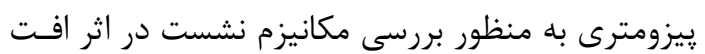

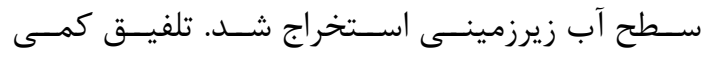

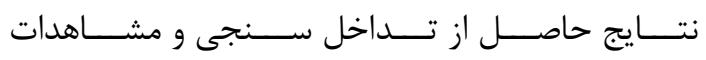

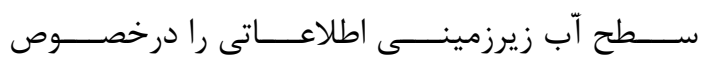
ضريب ذخيره سفره در اختيارقرار مى دهد.

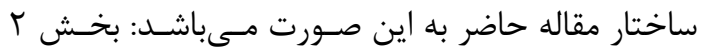

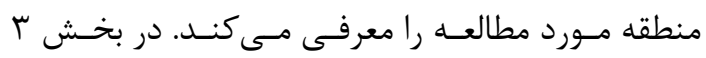
دادههاى مجموعه داده هاى مورد استفاده در اين مقالـه

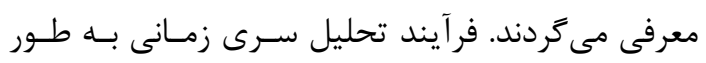

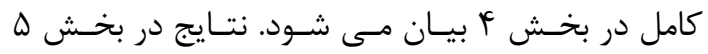
ارائه مىشـود. مقايسـه جابجاييهـاى اسـتخراج شـده از داز

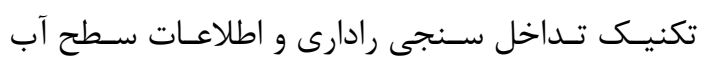

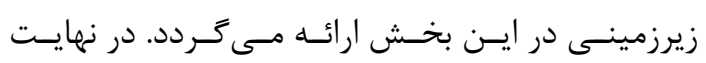
بخش 9 نتايج كلى را بيان مى كند.

\section{r- - منطقه مورد مطالعه}

مشهد در شمال شرق ايران بين رشته كوههاى بينـالود و هزارمسجد با روند شمال غرب-جنوب شرق قرار دارد.

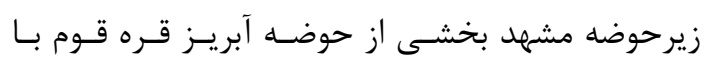

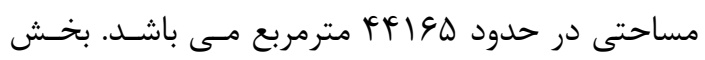

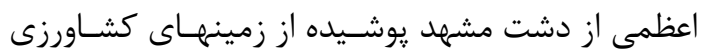

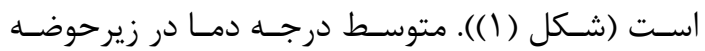

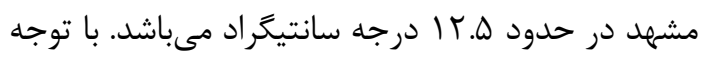

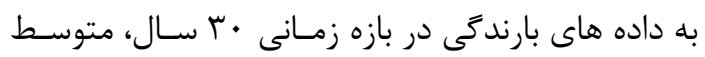

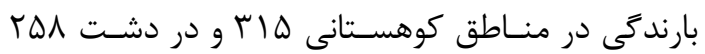

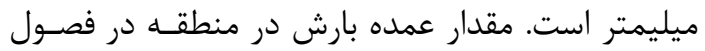

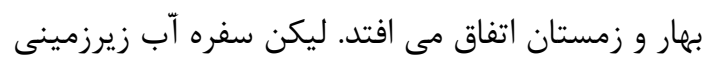

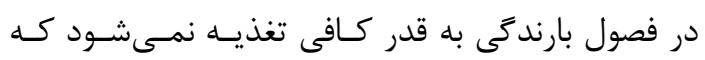

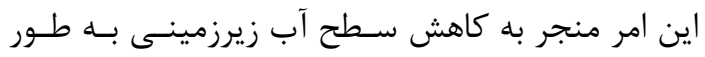

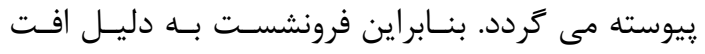
سطح آب زيرزمينى رخ مئدهد.

1 Descending 
نتايج حاصـل از روش بيشــــهادى مــورد اسـتفاده

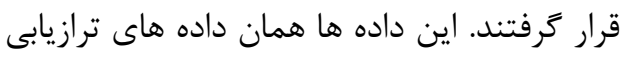

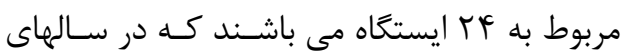

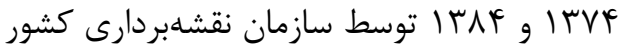
جمعآورى شده است. مسـير ترازيـابى دادههـا در

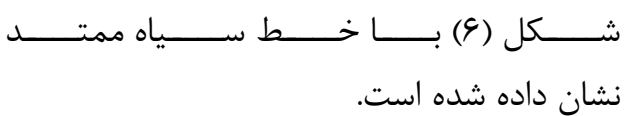

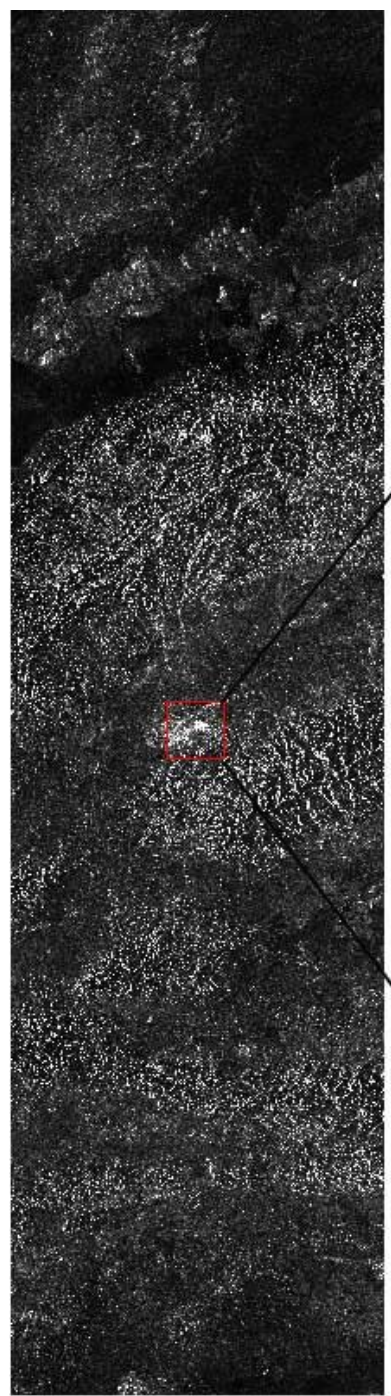

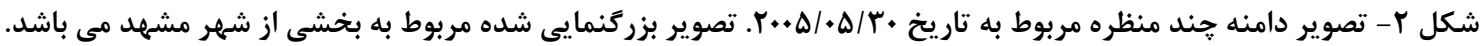

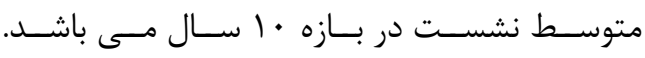

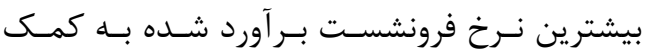

مقدار فرونشست زمين به كمك مشاهدات اين بـازه

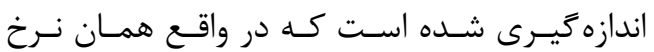


خارج از منطقه فرونشست (مانـــد خاههـاى شـماره

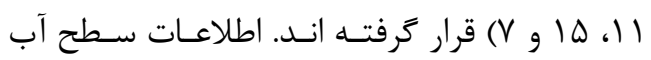

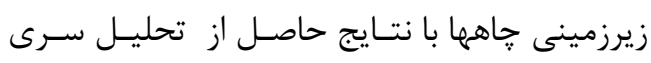

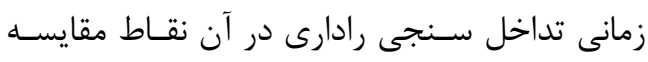

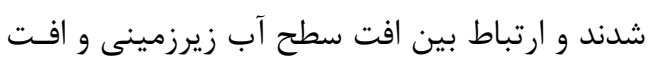
سطح زمين مورد ارزيابى قرار كرفت.

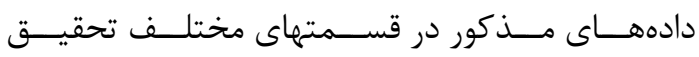

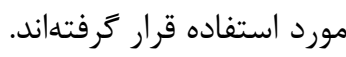

\section{ץ- تحليل سرى زمانى تداخل سنجى رادارى}

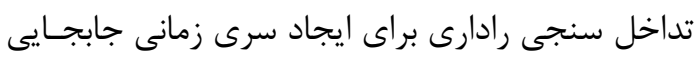

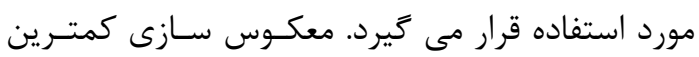

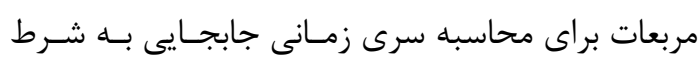

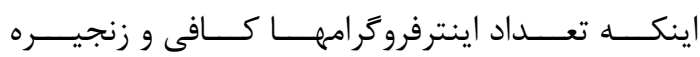
اينترفروخرامها كسسته نباشد به كار مىرود. در تحليـل سرى زمانى، مقادير جابجايى براى هر تاريخِ اخذ تصوير

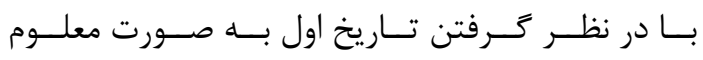
برآورد مىشوند. فاز تداخل سنجى رادارى كه از اختلاف نـاف

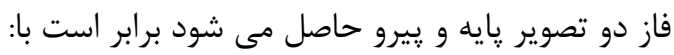

دادهاى ترازيابى در حدود V Vانتيمتر مى باشـد. با توجه به شكل (9) مشاهده مسى شـود كـه مســير

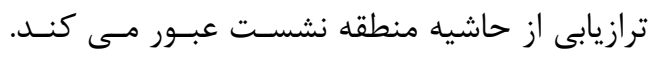

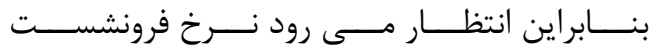
در كل منطقه از اين مقدار بيشتر باشد. اين مطلب در نتايج به وضوح مشخص خواهد شد.

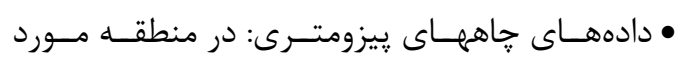

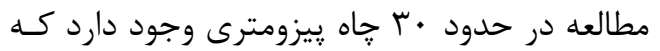

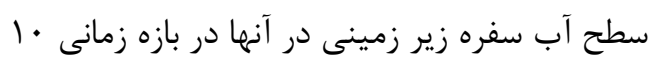

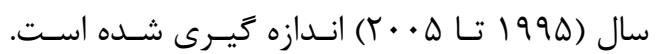

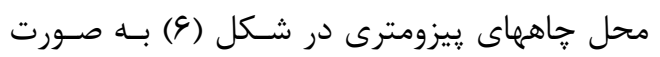

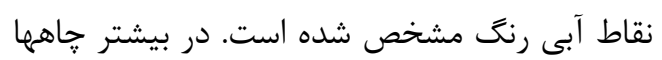

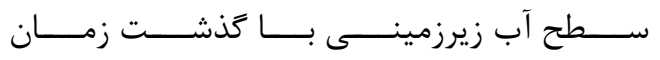

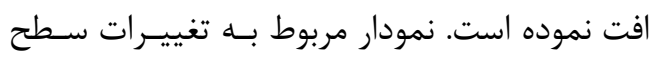

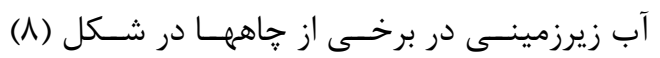

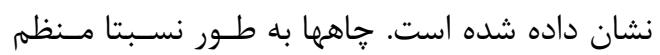
در سطح منطقه بخش شده اند. با توجـهـ بـهـ شـكل

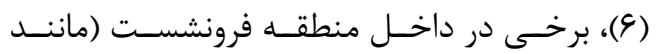

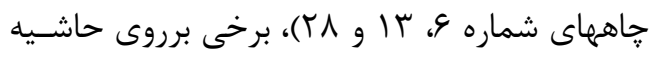

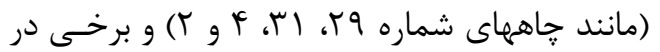

$$
\psi_{x, i}=W\left\{\phi_{D, x, i}+\phi_{A, x, i}+\Delta \phi_{S, x, i}+\Delta \phi_{t o p o, x, i}+\phi_{N, x, i}\right\}
$$

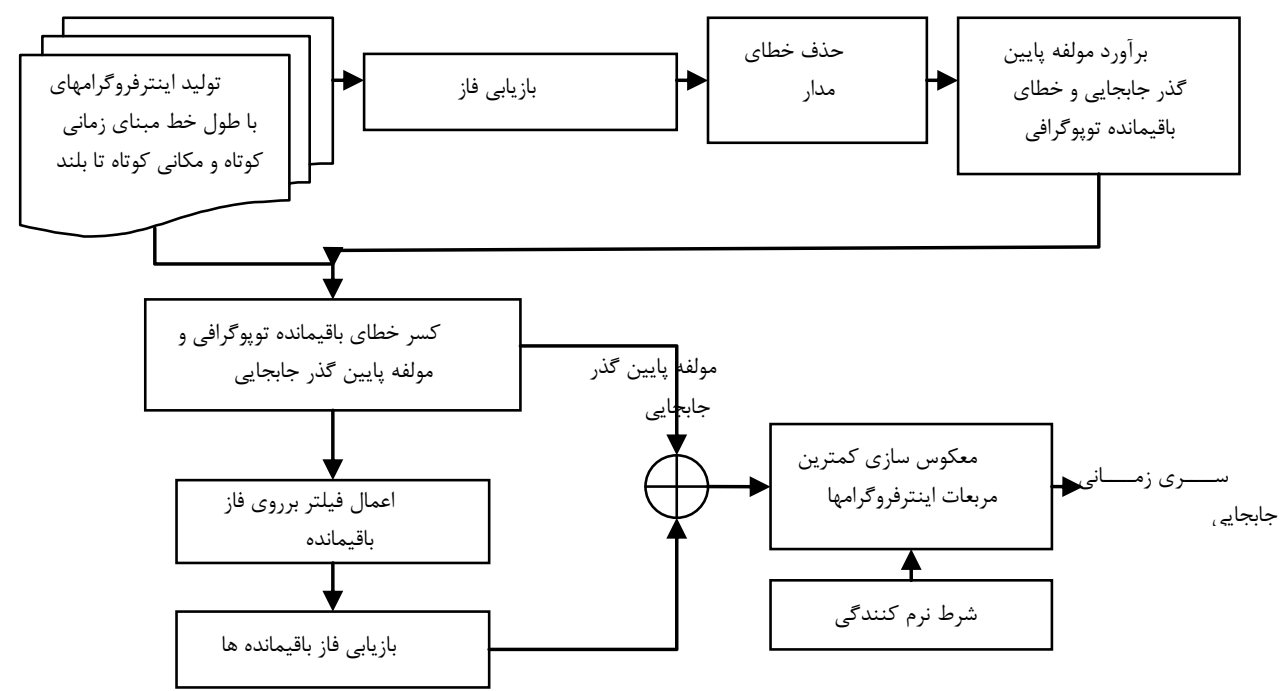

شكل r- نمودار روش تحليل سرى زمانى جابجايى 


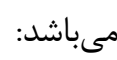

(T) رابطى (T)

$$
\phi\left(t_{i}\right)=\bar{v} \cdot\left(t_{i}-t_{0}\right)+\frac{1}{2} \bar{a} \cdot\left(t_{i}-t_{0}\right)^{2}+\frac{1}{6} \Delta \bar{a} \cdot\left(t_{i}-t_{0}\right)^{3}
$$

مؤلفه پِايين كذر جابجايى مسىباشـد. منظــور از

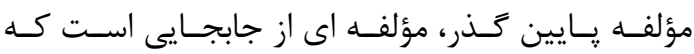

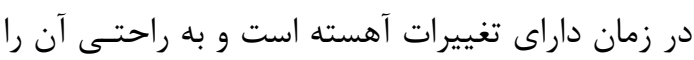

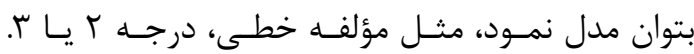
يارامترهـاى مؤلفـهـ جابجـايى شـامل سـرعت، شـــاب و و

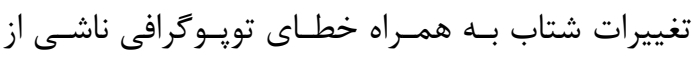

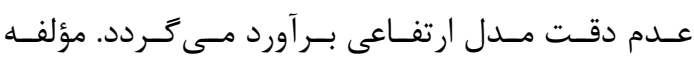

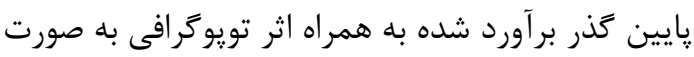

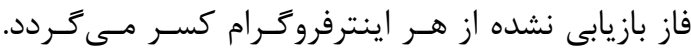

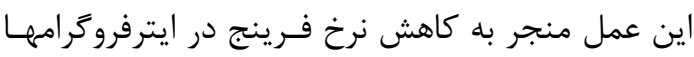

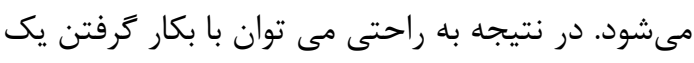

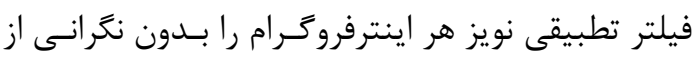

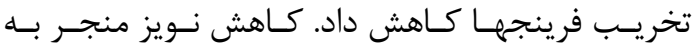
افزايش دقت بازيابى فاز مى كردد. فاز بازيابى شده نهايى

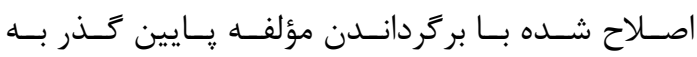

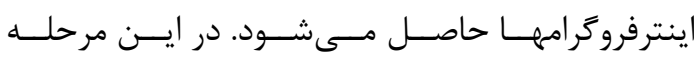
اينترفروكرامها از طريق حل كمترين مربعات به مقــادير جابجايى در هر تاريخ تبديل مىشوند. بلمنظور كـاهش

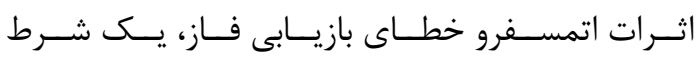

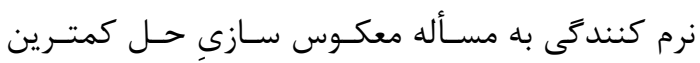
مربعات اضافه مىشود. اين شرط نرمكنــدكى برمبنــاى

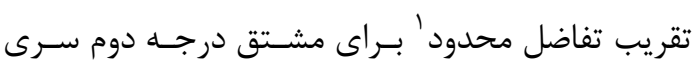

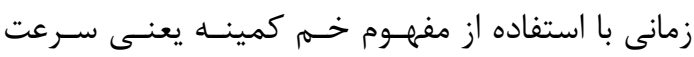

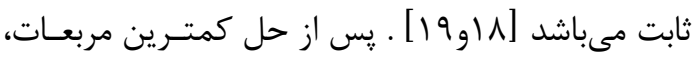
مقدار جابجايى در هر تاريخ بدست مى آيد.

1 Finite difference approximation
كه در آن

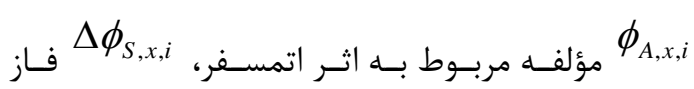
مربوط به اثر خطاهاى مدارى، اثر تويوگرافى باقيمانده ناشى از عدم دقت مدل ارتفاعى اسـتفاده شــده و عدم همبستگى مىباشد. از ميان مؤلفـه هـاى بـالا اثـر

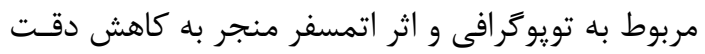

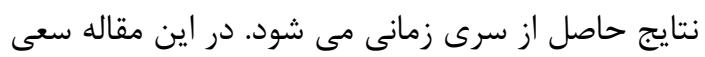

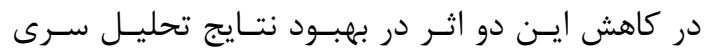
زمانى داريم. شـايان ذكـر اسـت، مؤلفـهـ هــاى ناشـى از

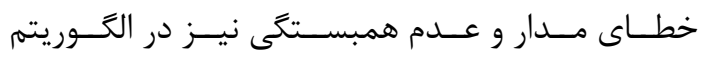
ي ريشنهادى كاهش مى يابند.

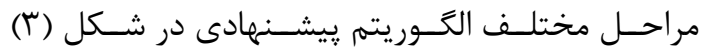

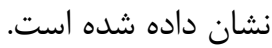
اصول اين الخَـوريتم توســـ براردينــو و همكــاران قـبلا

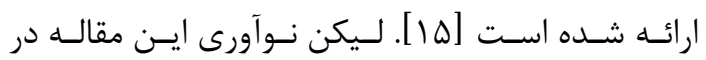

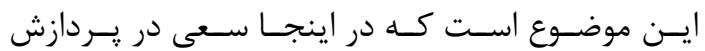

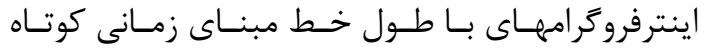

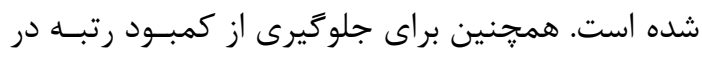
ماتريس ضرايب حل كمترين مربعات اينترفروكرامهاى

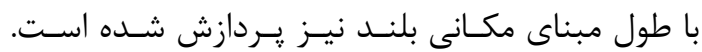

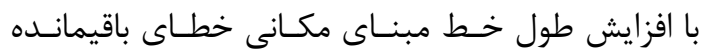

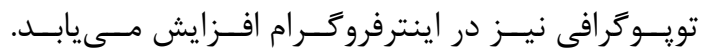

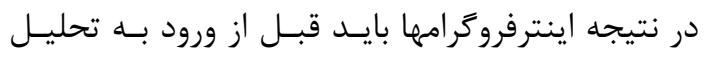
سرى زمانى اصلاح شـوند. يـس از مرحلـه باريـابى فـاز،

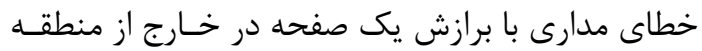

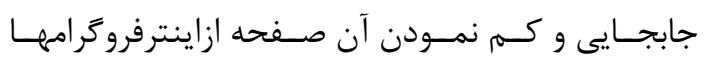

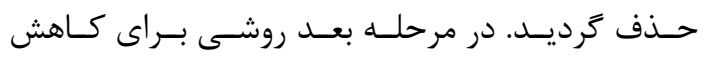

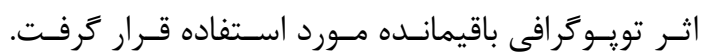

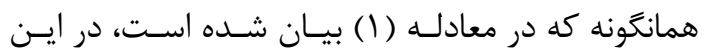
روش فرض مىشود كه فاز تـابعى از سـرعت جابجـايى،

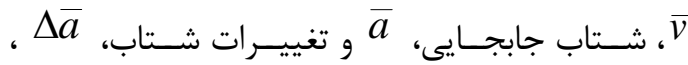




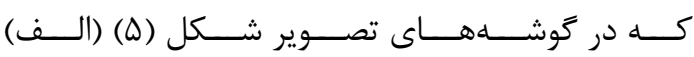

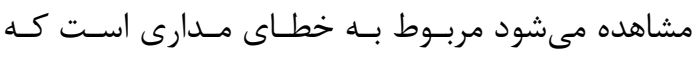

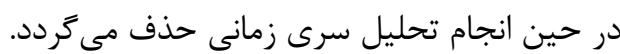
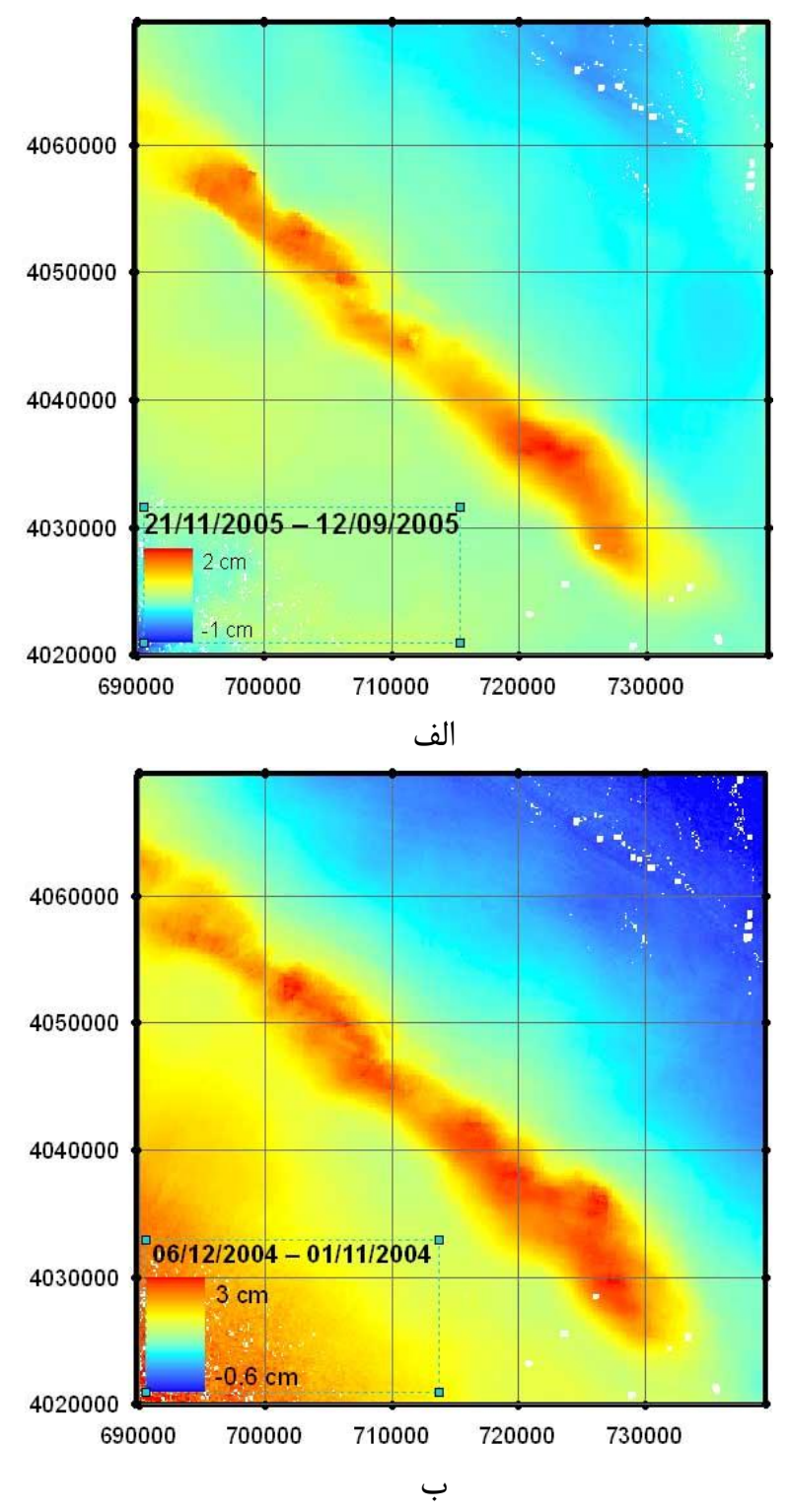

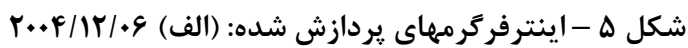
$r \cdot \Delta / \cdot q / / r-r+\Delta / 11 / r /$ (ب)
ه- نتايج حاصل از تحليل سرى زمانى InSAR در تكنيــك تــداخل ســـنجى متـــداول مــــبايســت

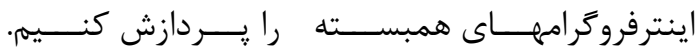

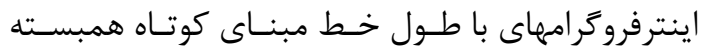
مىباشند و به راحتى فاز آنهـا قابـل بازيـابى مـىبـاشـد. در ايسن مطالعـه، 11 اينترفروخــرام بــه كمـك تصـاوير ENVISAT ASAR

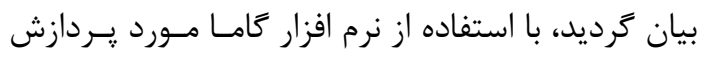

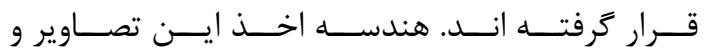
اينترفرو كرامهاى يردازش شده به صورت خطوط ممتـد

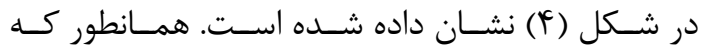
مشاهده مى شـود، اينترفروگرامهــا بيشـتر داراى طـول

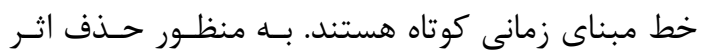

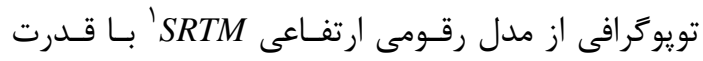
تفكيك مكانى •9 متر استفاده شد.

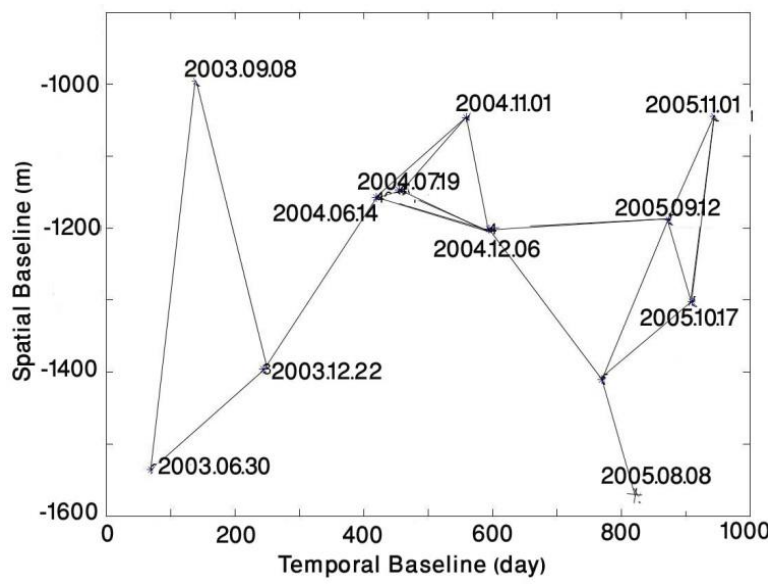

شكل F - هندسه اخذ تصاوير رادارى در منطقه مورد

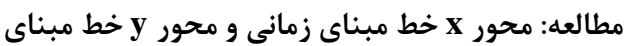

$$
\text { مكانى را نشان مى دهد. }
$$

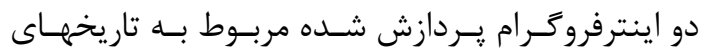
$-r \cdot \Delta /|1 / r| \quad, \quad r \cdot r / 11 / \cdot|-r \cdot r /| r / \cdot \varphi$

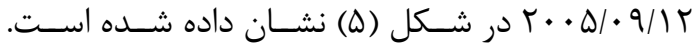
سيخنال مربوط به جابجايى به وضوح در مركز شكل بـه

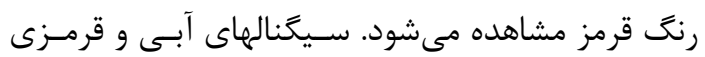

1 Shuttle Radar Topography Mission 


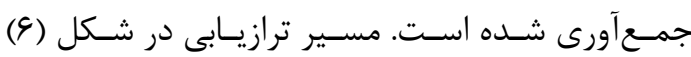
بلهورت خط سياه مشخص شده اسـت كـه از حاشـيه

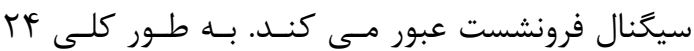

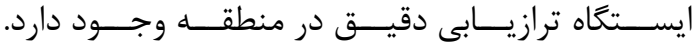
نرخ جابجـايى بدسـت آمـده از تـداخل سـنجى رادارى درى

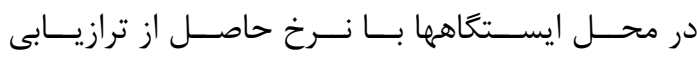
مورد مقايسه قرار گرفت و خطــاى RMSE بــين نتــايج حاصل از تداخل سنجى رادارى و ترازيابى به مقدار 9. سانتيمتر در سال بر آورد شدكه نشان دهنده دقت بالاى

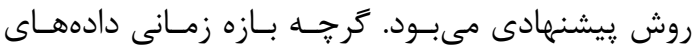

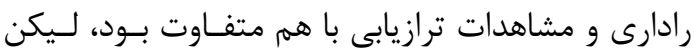

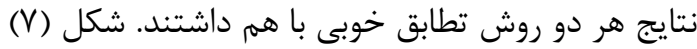
انطباق نتايج حاصل از هر دو روش را نشان مىدهد.

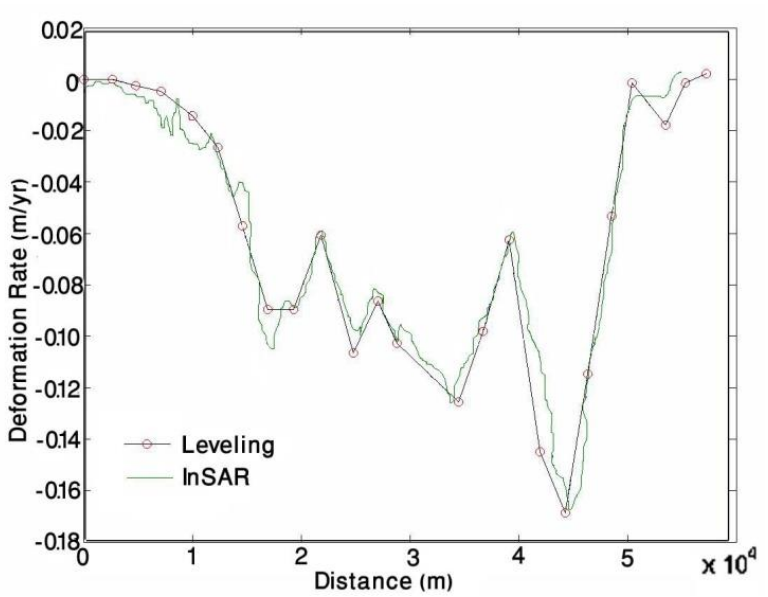
شكل V - مقايسه نرخ جابجايى حاصل از تحليل سرى زمانى تداخل سنجى رادارى و ترازيابى لمانى

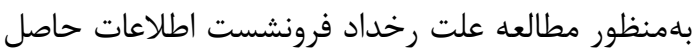
از تحليل سرى زمانى را با اطلاعات سطح آب زيرزمينى

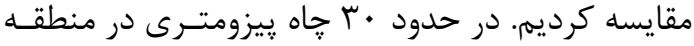
فرونشست وجود دارد كه اطلاعات سطح آب زيرزمينسى مئى

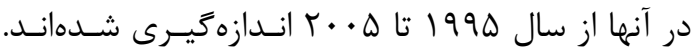
در بيشتر جاهها افـت سـطح آب زيرزمينـى بـهـ وضـوح مشـاهده مسى گـردد. نوسـانات سـطح آب در برخـى از جاههايى كه در منطقه نشست و اطراف آن قرار دارنسد، در شكل (N) نشان داده شده است. با مقايسه شـكلهاى مداى

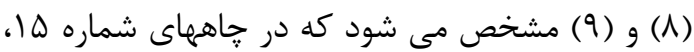

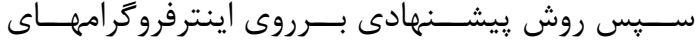

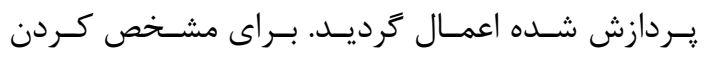
عوارض شاخص فرونشست در سـحح زمسين و بررسى نسى

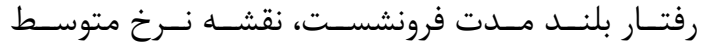
فرونشست به كمك نتايج حاصل از تحليل سرى زمـانى استخراج شد (شكل (()). بيشينه مقدار نرخ فرونشست

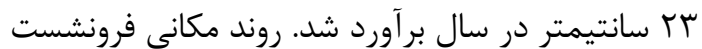
در جهت شمال غرب-جنوب شرق مى باشد كـه شـبيه روند ارتفاعات در منطقه است. بنـابراين الكَـوى مكـانى

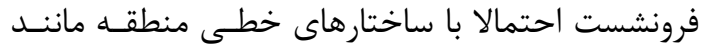
كسلها كنترل مى گردد (شكل (9) را ببينيد).

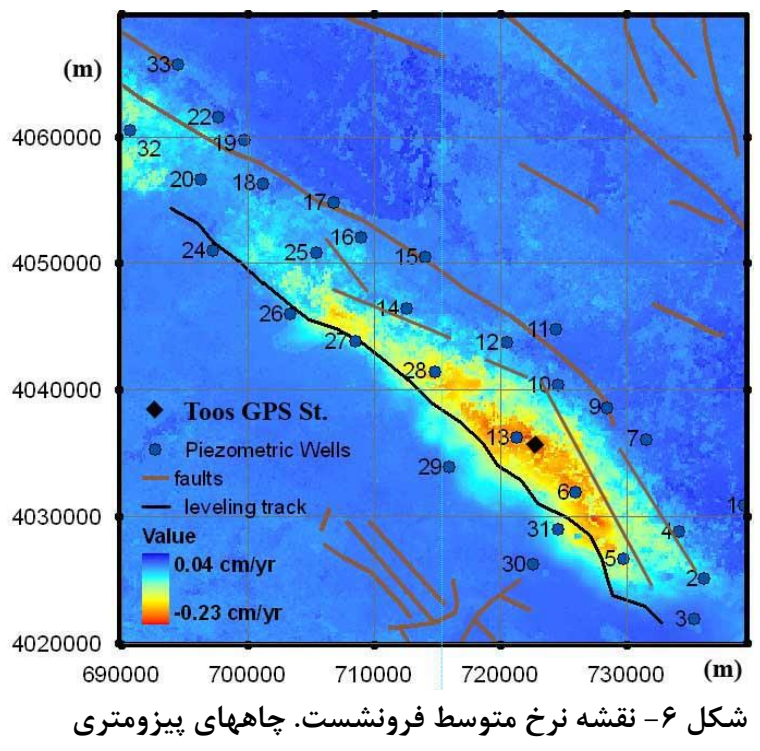
با دواير آبى رنت نشان داده شده است. خطوط در در تصوير، كسلها و خطواره ها مى باشند.

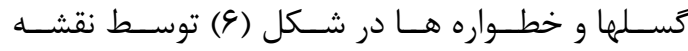

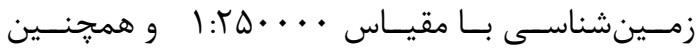

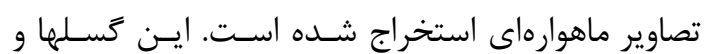
خطوارهها مانند يك سد در سفره آب زيرزمينـى عمـل مى كنند كه جريان آبهاى زيرزمينى را كنترل مى كنند. براى ارزيابى نتايج، نرخ متوسط حاصله از تحليل سـرى زمانى جابجايى را با نرخ متوسـط حاصـل از مشـاهدات ترازيابى مقايسه نموديم. مشاهدات ترازيابى در سـالهاى MVF 
دليل خروج آب از بـين آنهـا، بـه ميـزان قابـل تـوجهى متراكم نمىشوند.

به منظور مقايسه نوسانات سطح آب زيرزمينى و سـطح زمين، سـرى زمـانى جابجـايى سـطح زمـين در همـان جاههاى يَيزومترى در شكل (9) نشان داده شده است.
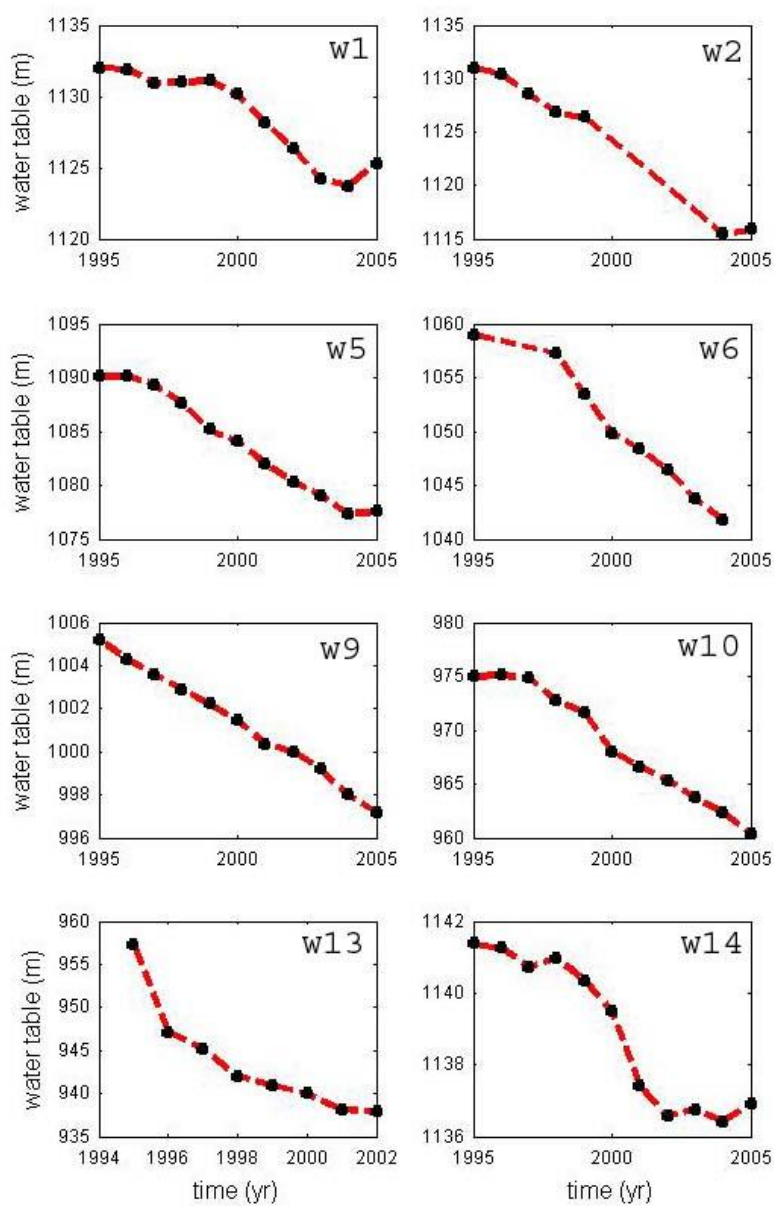
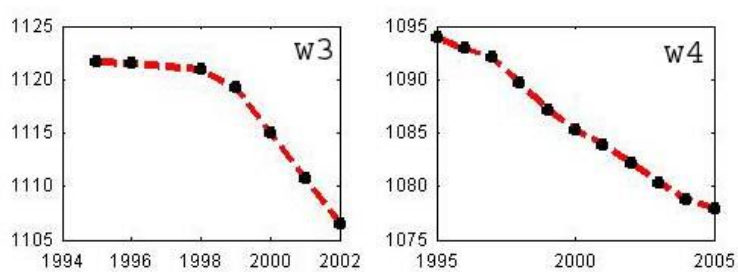

19 و rا كه در خارج از منطقه فرونشست قـرار دارنـد، افت سطح آب نيز ناجيز است. از طرفى ديگر، در برخى

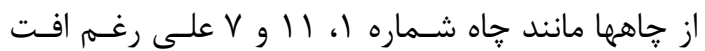
شـديد ســطح آب، فرونشسـت مشــاهده نمــى خــردد. اين مسأله مى تواند به دليل جنس آبخوان در آن مناطق فرونش باشد. به طور كلى رسـوبات درشـت دانسه درجــه تـراكم يذيرى يايينى دارند و لذا با افزايش تنش بين ذرهاى به به
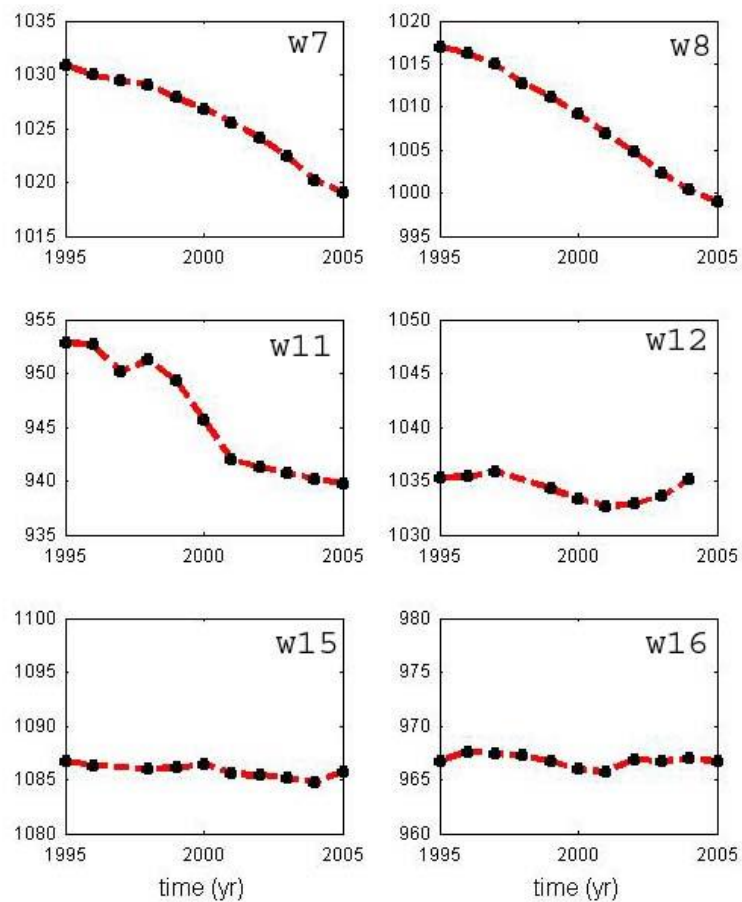

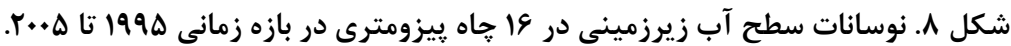



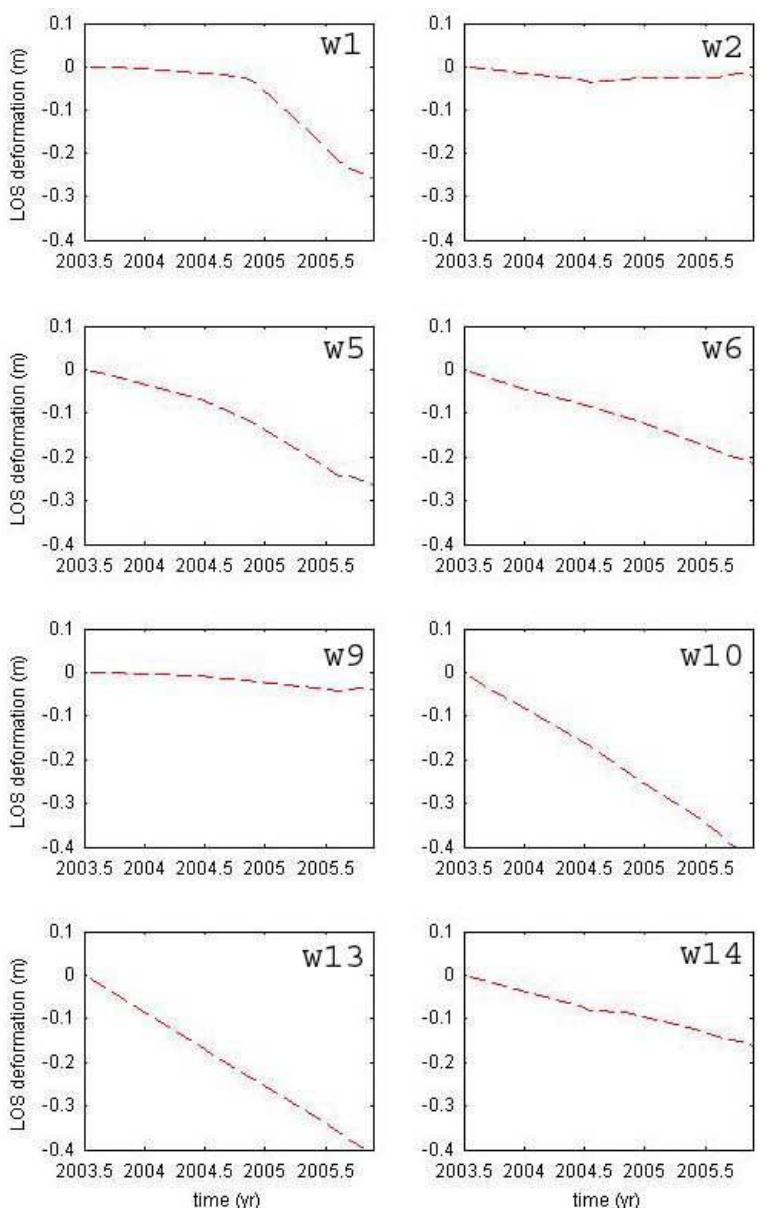

كترى كه افت سطح آب در آنها
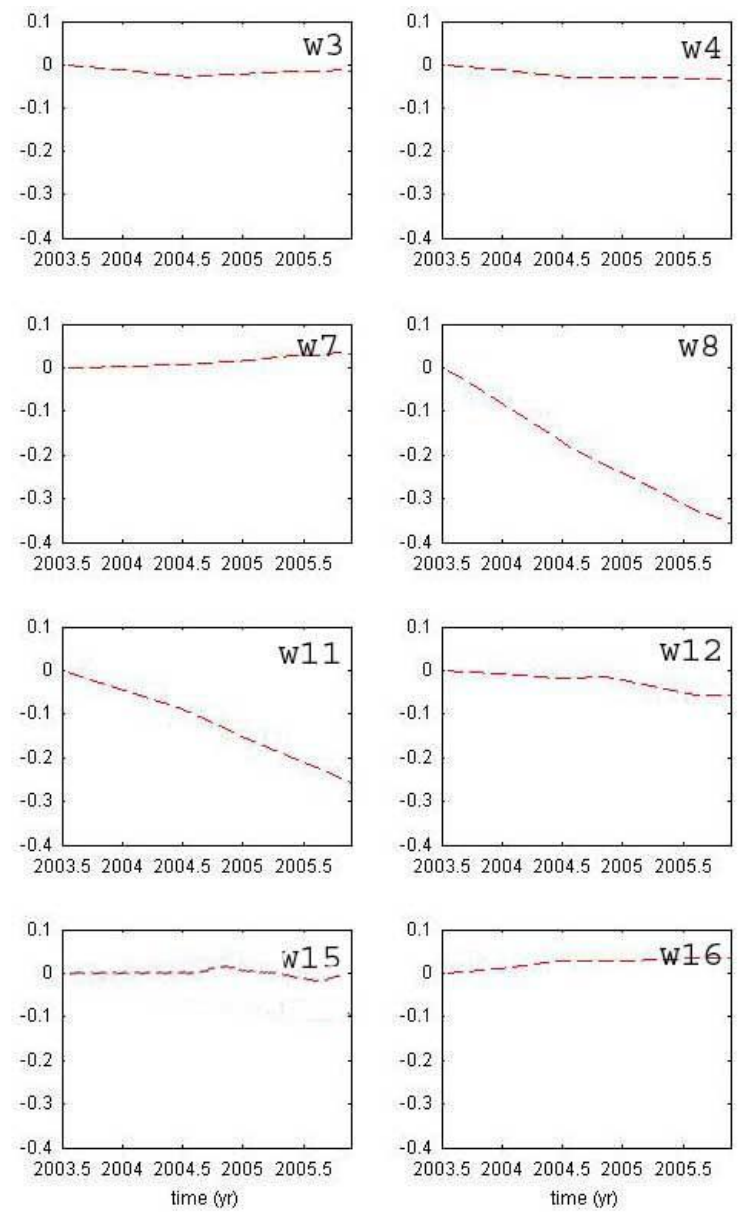

شكل 9
تداخل سنجى رادارى كه نشـان دهنـده ميـزان تـراكم

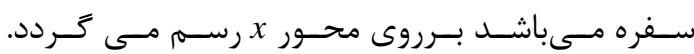
يك برآورد تقريبى از ميزان ضريب ذخيسره كلهى سـفره

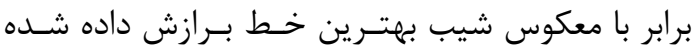
بر اين نمودار مى گردد [ب]. به طور كلى ميزان ضريب ذخيره سفره كه شامل پاســخ سفره و ميـان لايـه هـاى ريزدانـه بـهـ تغييـرات سـطحح

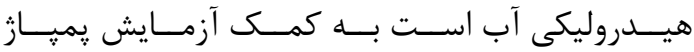
تعيين مى گردد. ليكن ضريب ذخيره تعيين شده در اين

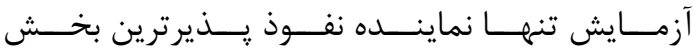
سفره آب زيرزمينى است. ضريب ذخيــه بــرآورد شـده

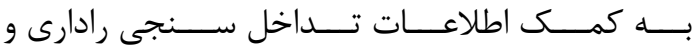

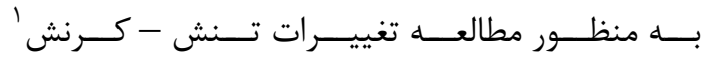
در زير حوضه مشهد، اطلاعات سـطح آب زيرزمينسى در جاههاى پيزومترى مورد تحليـل قـرار گرفتـ. مكـانيزم تراكم و رابطه تنش - كرنش در سفره آب زيرزمينسى از اطلاعات تـداخل ســنجى رادارى و مشــاهدات همزمـان سطح آب زيرزمينى استخراج شـدند. يكـى از روشـهاى

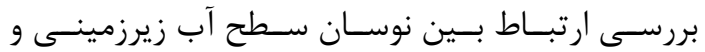

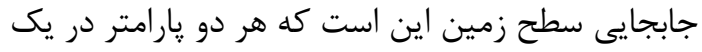

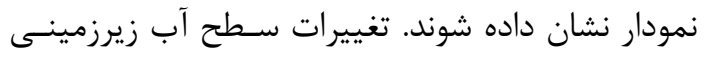

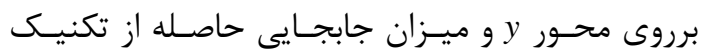

1 Stress-strain 
مى تواند منجر به پِيش بينى مقدار فرونشسـت بـه ازاى افت مشخصى از سطح آب كردد.

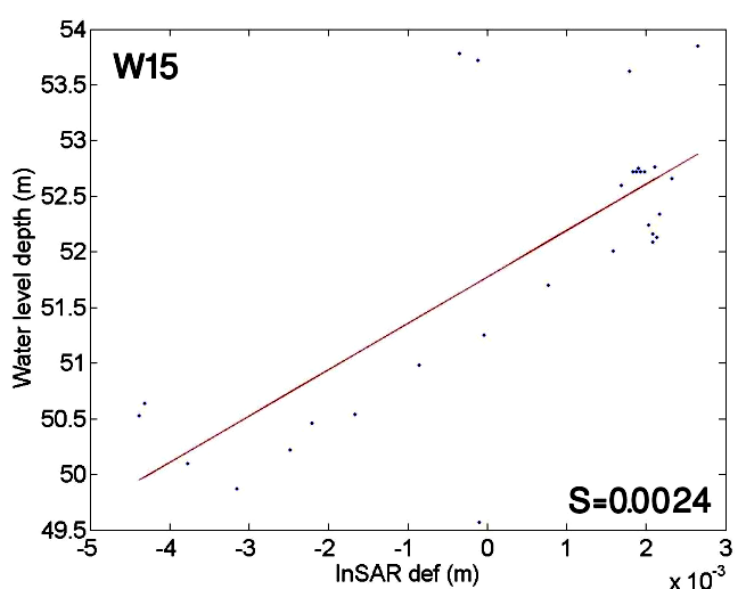

(ب)
اندازه كيريهاى سطح آب زيرزمينى برآوردى را در محل

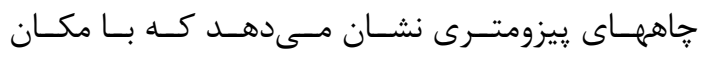

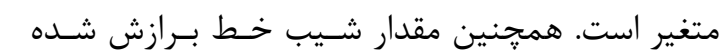

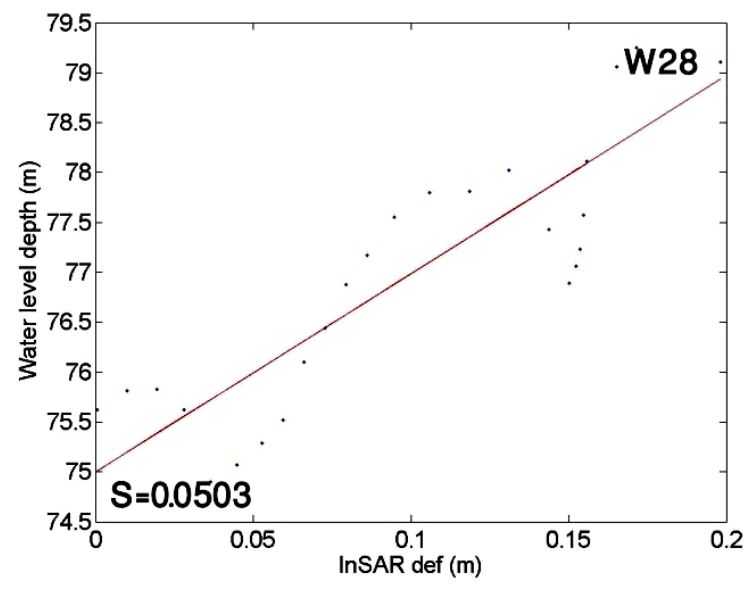

(الف)

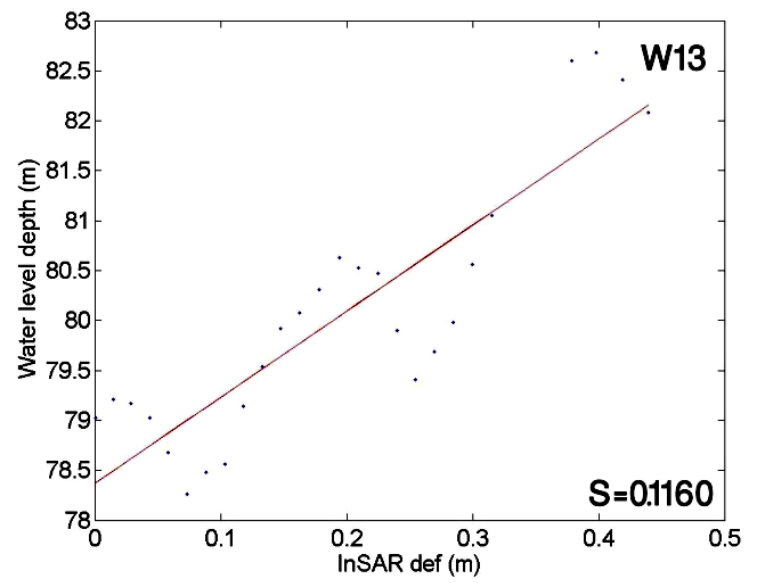

(ج)

شكل •|- ضرايب ذخيره محاسبه شده از تحليل سرى زمانى جابجايى و اطلاعات سطح آب زيرزمينى جاهيهاى W15 (خارج إز

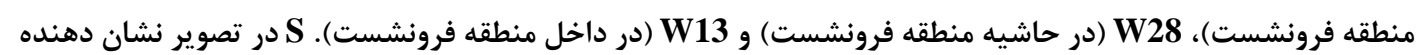

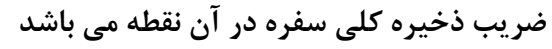

نشان داده شده است. خط برازش داده شده مسى توانـــ

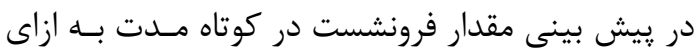

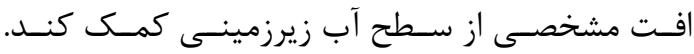
در شكل (•) (الف) و (ج) مشاهده مى خردد كه نمودار

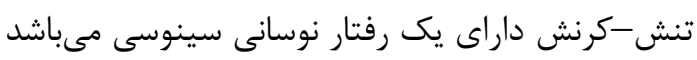
كه به دليل تخليه و تغذيه آبخوان در فصول تابسـتان و واني

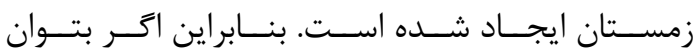

تغييرات سطح آب كه با جابجايى سطح زمـين در يــ

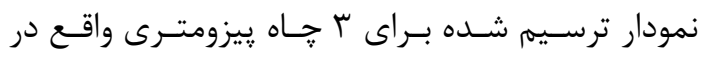
وسط، حاشيه و خارج منطقه فرونشست، در شكل (• (1) نشان داده شـده اسـت. خـط قرمـز رنــ در نمودارهـا

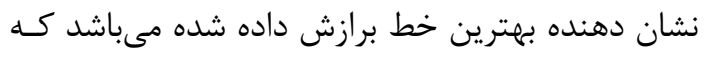

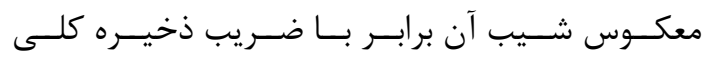

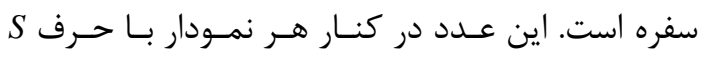


سرى زمانى شوند، مىبايست ״ـالايش شـوند. همجنـــــن

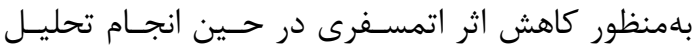

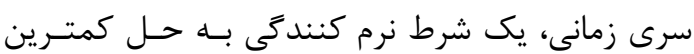
مربعات اضافه مى كردد.

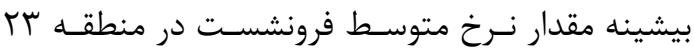
سانتيمتر در سال برآورد شد. سرى زمانى جابجايى كـهـ

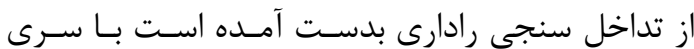
زمانى سطح آب زيرزمينى به طور كمى با هـم مقايسـهـ

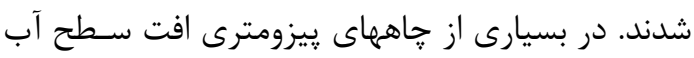

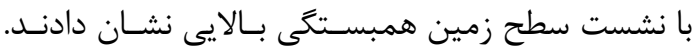

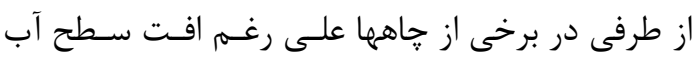
زيرزمينى سيخنال فرونشست وجود نداشت. دليـل ايـن إنـ

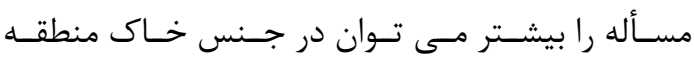

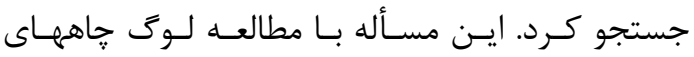
ي يزومترى مشخص مى كردد.

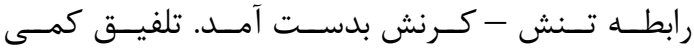

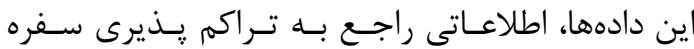

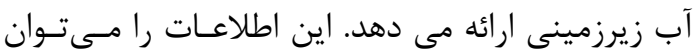

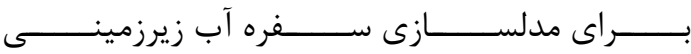

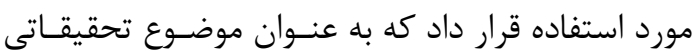
آتى مىتواند در نظر كرفته شود.

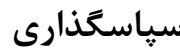
برخود لازم مي دانيم از آزانس فضـايى ارويـا (ESA) بـــــ خاطر در اختيار قرار دادن داده هاى ENVISAT ASAR

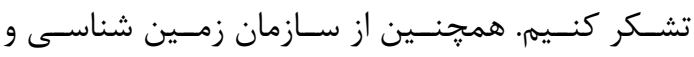

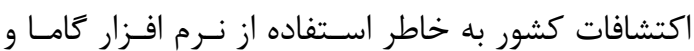
اطلاعات خاههاى پيزومترى كمال تشكر را داريم.

[1] K. Terzaghi, "Principles of soil mechanics, IV, settlement and consolidation of clay,". Eng. News Rec.,vol. 95, pp. 874-878, 1925.

[2] J. Hoffmann, S.A. Leake, D. L. Galloway, and A.M. Wilson, "MODFLOW-2000 ground-water model-user guide to the subsidence and aquifer-system compaction
به اين سريهاى نوسانى تابع برازش داد، مىتوان با دقت بالاترى پيش بينى نشست سطح زمين را انجام داد.

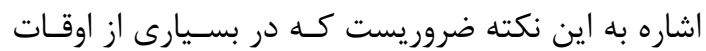

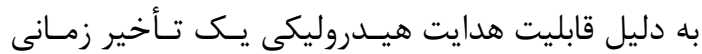

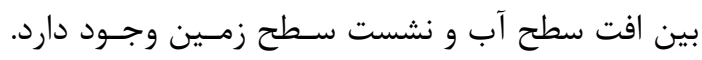

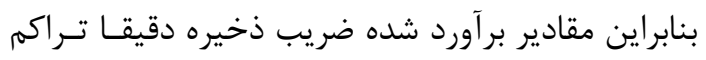

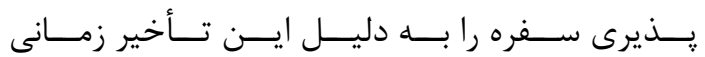
نشان نمىدهد. به منظور برآورد دقيق تر ضريب ذخيره سفره، اطلاعات ديخرى از جمله ضخامت ميان لايههـا و

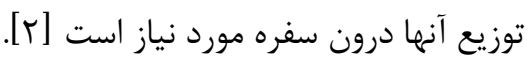

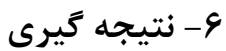
كمبود بارش به دليـل تغييـر اقلـيم منجــر بــهـ افزايش

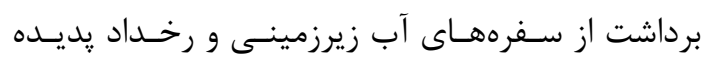
فرونشست مى كـردد. فرونشست در اثر خشكسـالى از رداز جمله يرهزينه ترين بلايابى طبيعى اسـت. اولـين اقـدام

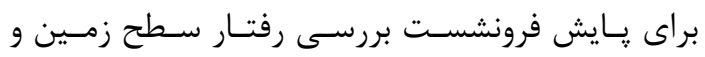

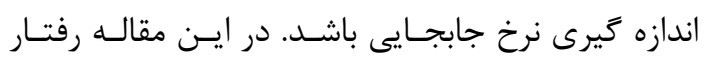

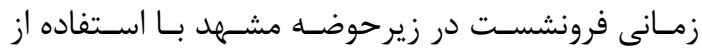
تحليل سرى زمانى جند مرحله اى برمبنـاى مشـاهدات

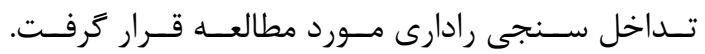
اينترفروكرامهاى يردازش شده تنها داراى خـط مبنـاى

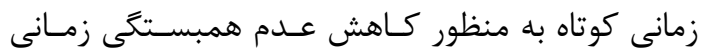

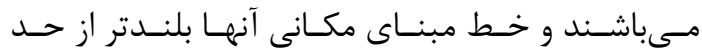

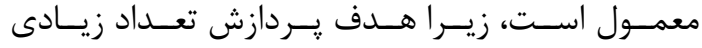

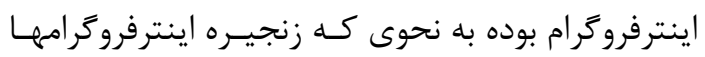

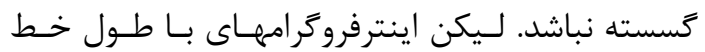

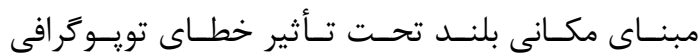

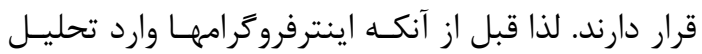

\section{مراجع}

(SUB) package," U.S. Geological Survey Open-File Report 03-233, 2003.

[3] J. Hoffmann, D.L. Galloway, H.A. Zebker, and F. Amelung, "Seasonal subsidence and rebound in Las Vegas Valley, Nevada, observed by synthetic aperture radar interferometry," Water Resour. Res., vol. 
ارائه الكَوريتمى جديد بر مبناى تكنيك تداخل سنجى ...

37(6), pp. 1551-1566, 2001.

[4] C.F. Tolman, and J.F. Poland, "Groundwater, salt-water infiltration, and groundsurface recession in Santa Clara Valley, Santa Clara County, California," Am. geophys. Un. Trans.,vol. 21, pp. 23-34, 1940.

[5] J.F. Poland, and G.H. Davis, "Land subsidence due to withdrawal of fluids," Rev. Eng. Geol.,vol. 2, pp. 187-269, 1969.

[6] D.L. Galloway, K.W. Hudnut, S.E. Ingebritsen, S.P. Phillips, G. Peltzer, F. Rogez, and P.A. Rosen, "Detection of aquifer system compaction and land subsidence using interferometric synthetic aperture radar, Antelope valley, Mojave Desert, California," Water Resour. Res.,vol. 34, pp. 2573-2585, 1998.

[7] D.L.Galloway, D.R. Jones, and S.E. Ingebritsen, "Land subsidence in the United States," US Geological Survey Circular, No.1182, p. 175, 1999.

[8] A. Alizadeh, "Mathematical models of Mashhad study area. Preliminary reports of the ministry of power," Regional water co. of Khorasan, Applied researches committee, 2004.

[9] F. Amelung, D.L. Galloway, J.W. Bell, H.A. Zebker, and R.J. Laczniak, "Sensing the ups and downs of Las Vegas-InSAR reveals structural control of land subsidence and aquifer-system deformation," Geology, vol. 27, pp. 483-486, 1999.

[10] G. Peltzer, P. Rosen, F. Rogez, and K. Hudnut, "Poro-elastic rebound along the Landers 1992 earthquake surface rupture," J. geophys. Res., vol. 103, pp. 30 131-30 145, 1998.

[11] B. Fruneau, and F. Sarti, "Detection of ground subsidence in the city of Paris using radar interferometry: isolation from atmospheric artifacts using correlation," Geophys. Res. Lett., vol. 27(24), pp. 39813984, 2000.

[12] M. Tesauro, P. Beradino, R. Lanari, E. Sansoti, G. Fornaro, and G. Franceschetti, "Urban subsidence inside the City of Napoli (Italy) observed with synthetic aperture radar interferometry at Campi Flegrei caldera", J. geophys. Res., vol. 27, pp. 1961-1964, 2000.

[13] M. Crosetto, C.C. Tscherning, B. Crippa, and M. Castillo, "Subsidence monitoring using SAR interferometry: reduction of the atmospheric effects using stochastic filtering," Geophysi. Res. Lett., vol. 29(9), pp. 26.1-26.4, 2002.

[14] M. Motagh, Y. Djamour, T.R. Walter, H.U. Wetzel, J. Zschau, and S. Arabi, "Land subsidence in Mashhad Valley, northeast Iran: results from InSAR, levelling and GPS,” Geophys. J. Int., 168, 2006.

[15] P. Berardino, G. Fornaro, R. Lanari, and E. Sansosti, "A New algorithm for surface deformation monitoring based on small baseline differential SAR interferograms," IEEE Trans. Geosci. Remote Sens., vol. 40, pp. 2375-2383, 2002.

[16] M. Dehghani, "Estimation of Deformtion Rate and Modeling of Land Subsidence Induced by Groundwater Exploitation using Interferometry", Ph.D. Thesis. K. N. Toosi University of Technology, 2009

[17] M. Dehghani, M. J. Valadan Zouj, J. Biggs, A. Mansourian, B. Parsons, and T. Wright, "RADAR Interferometry Time Series Analysis of Mashhad Subsidence, "Journal of International Society of Remote Sensing (ISRS), vol. 37(1), pp. 147-156, 2009.

[18] D. A. Schmidt, and R. Burgmann, "Timedependent land uplift and subsidence in the Santa Clara valley, California, from a large interferometric synthetic aperture radar data set" , J. geophys. Res., vol. 108(B9), pp. 2416, 2003.

[19] P. Lundgren, S. Usai, E. Sansosti, R. Lanari,, M. Tesauro, G. Fornaro, and P. Berardino, "Modeling surface deformation observed with SAR interferometry at Campi Flegrei Caldera," J. geophys. Res., vol. 106, pp. $19355-19367,2001$. 



\title{
An Enhanced Algorithm based on Radar Interferometry for Monitoring Land Subsidence Caused by Over-Exploitation of Groundwater
}

\author{
Maryam Dehghani $^{1^{*}}$ \\ 1 Assistant Professor of Dept. Of Civil and Environmental Engineering, School of Engineering, Shiraz University
}

\begin{abstract}
Over-exploitation of groundwater has caused land subsidence in large rural areas located in Mashhad subbasin, northeast of Iran. Time series analysis using Interferometric SAR (InSAR) data has shown its ability to monitor the temporal evolution of land subsidence. In this paper, time series analysis based on Small Baseline Subset (SBAS) algorithm is applied to study the Mashhad sub-basin subsidence. 18 interferograms were generated using 12 ENVISAT ASAR images spanning between 2003 and 2005. In order to decrease the temporal decorrelation effect caused by the agricultural fields, only interferograms with small temporal baselines are used in the time series analysis. However, to prevent the solution from the rank deficiency, it is tried to generate as many interferograms as possible. Because the interferograms with large spatial baselines are influenced by the topographic artifacts, they are refined before using in the time series analysis. Moreover, the atmospheric-error free deformation corresponding to every acquisition time is retrieved by applying the smoothing constraint into the least squares solution. The maximum deformation rate in the study area is estimated as $\sim 23 \mathrm{~cm} / \mathrm{yr}$. The compressibility of the aquifer system is finally investigated by the quantitative integration of the InSAR displacement measurements with observations of the hydraulic head fluctuations at few piezometric wells.
\end{abstract}

Key words: Radar Interferometry, Time Series Analysis, Subsidence 